\title{
Pharmaceutical and Biomedical Research
}

\section{A review of acrylamide toxicity and its mechanism}

\author{
Ehsan Zamani ${ }^{1,2}$, Mohammad Shokrzadeh $^{1}$, Marjan Fallah $^{1,2}$, Fatemeh Shaki ${ }^{1 *}$ \\ ${ }^{1}$ Department of Toxicology and Pharmacology, Faculty of Pharmacy, Mazandaran University of Medical Science, Sari, Iran \\ ${ }^{2}$ Student Research Committee, Mazandaran University of Medical Sciences, Sari, Iran
}

Received: Feb 12, 2017, Revised: Mar 14, 2017, Accepted: Apr 9, 2017

\begin{abstract}
Acrylamide (AA) is an important industrial chemical agent that is mainly used in the production of polymers and copolymers. Recently it has been attention because of its production in the diet at high-temperature $\left(>120^{\circ} \mathrm{C}\right)$ processes such as cooking, frying, toasting, roasting or baking of high carbohydrate foods. According to high exposure to acrylamide, recognition of its toxic effect is necessary. Neurotoxicity, reproductive toxicity and immunotoxicity of AA were observed in several studies. There isn't a clear mechanism that justifies this toxicity. In this study we reviewed the mechanisms of AA toxicity especially oxidative stress and apoptosis. AA can cause neurotoxicity, reproductive toxicity and genotoxicity on animal models. It showed neurotoxicity in human. We suggested the oxidative stress is the main factor for inducing of acrylamide toxicities. We advised that modifying of food processing methods can be as a good way for decreasing of AA production in foods.
\end{abstract}

Keywords: Acrylamide, toxicity, mechanism, kinetic, human, animal

Pharm Biomed Res 2017; 3(1): 1-7

\section{Introduction}

Acrylamide (AA) is an important manufacturing chemical agent that is used for producing of polymers and copolymers. Also, AA has been intended for producing grouts and soil stabilizers since 1970 (1). The importance of AA as a food contamination was shown when Tareke et al. observed that feeding rats with fried feed showed a large increase in the level of the hemoglobin adduct (2). AA is formed in food when high carbohydrate foods prepares at high-temperature $\left(>120{ }^{\circ} \mathrm{C}\right)$ processing such as cooking, frying, toasting, roasting or baking. It happens when amino acid asparagine reacts with sugars especially glucose and fructose as a result of the Maillard reaction (3).

International Agency on Research on Cancer (IARC) classified AA as "probably carcinogenic to humans". In 2001, the Scientific Committee on Toxicity, Ecotoxicity and the Environment revealed acrylamide's inherent toxic properties such as neurotoxicity, genotoxicity in both somatic and germ cells, carcinogenicity, and reproductive toxicity(4). In 2002, Swedish National Food Administration added AA to the list of neo-formed contaminants (NFCs) when it was identified in several heat processing, carbohydrate-rich foods, such as potato chips, crisps, coffee and bread (5).

In 1997, a large water leakage happened during the building of a tunnel in Sweden. Tunnel's walls were contained monomer of AA and other acrylamide's derivatives such as Nmethylolacrylamide. Leakage of these compounds into the environment killed fish and paralyzed cattle near the construction site (4).

Due to the wide exposure to AA in food and environment, we focused on the last achievements about AA properties and toxicity.

\section{Physicochemical properties of acrylamide}

AA is an odorless and colorless crystalline solid at room temperature. Its molecular formula is $\mathrm{CH}_{2}=\mathrm{CH}-\mathrm{CO}-\mathrm{NH}_{2}$ and molecular weight is 71.08 . AA boiling point is $125^{\circ} \mathrm{C}(25 \mathrm{~mm}$ $\mathrm{Hg}$ ), and melting epoint is at $84.5^{\circ} \mathrm{C}$, and density is $1.27 \mathrm{~g} / \mathrm{ml}$ $\left(25^{\circ} \mathrm{C}\right)$. It is readily soluble in water and polar solvent such as acetone, methanol and ethanol. It is almost insoluble in nonpolar solvents such as carbon tetrachloride (6).

\section{Acrylamide toxicokinetic}

AA is a small organic molecule with electrophilic vinyl group which may be attacked by nucleophiles. It is demonstrated that this compound has a rapid and

complete uptake through gastrointestinal track in rats (1). It is reported that absorption through rat skin is not complete. To prove this point Ramsey et al. calculated that the absorption of AA through the skin is $25 \%$ of the applied doses ( 2 or $50 \mu \mathrm{g} / \mathrm{kg}$ ) (1). Toxicokinetic researches in humans have shown a terminal elimination half-life of $2.4-7.0 \mathrm{~h}$ for AA (7). AA can be metabolized by Cytochrome P450 2E1 (CYP2E1) leading to 
produce an epoxide derivative such as glycidamide, which is more reactive to attack toward DNA and proteins than the parent compound (8). AA and glycidamide (its metabolite) are conjugated with glutathione (GSH) then eliminated as byproducts of mercapturic acid in human urine (9). Moreover previous studies showed that AA reduced GSH storage (10-11). It is shown that hepatic GSH-S-transferases catalyze the reaction of AA and GSH (12). In another study the authors assessed the kinetics of AA in various doses $(0.5-100 \mathrm{mg} / \mathrm{kg})$ after i.v or oral administration. It quickly distributed throughout the body (13). Approximately $12 \%$ of the compound rapidly accumulated in RBC with high concentration for at least 10 days. This persistence has been supposed to result from the reaction of AA with sulfhydryl groups present in hemoglobin (10). Miller et al. evaluated the higher percentage of this compound in muscle (48\%), skin (15\%), blood (12\%) and liver (7\%), while the neural tissues (brain, spinal cord, and sciatic nerve) contained less than $1 \%$ (14).

\section{Food exposure}

According to national dietary patterns and food preparation methods, the different level of AA in foods were reported in each country. Potato products, coffee, and bakery products are the most important sources. Direct exposure to AA usually is a result of consuming high-carbohydrate foods such as potato crisps, chips, roasted cereals and breads. Also food packaging with polyacrylamide leads to indirect exposure to AA monomer residual (15). Therefore Estimation of AA intake from food product is a concern in many countries.

In the basis of reported data, potato products alone is accounted for $50 \%$ of human exposure to AA. $20 \%$ of this ranking is belong to baking products and bread. Bakery goods, bread and rolls have little AA but the highest levels have been detected in the crust of the bread, and the bread crumb contains almost no AA (16). K. Svensson et al. showed potato crisps have highest AA amounts (1360 $\mu \mathrm{g} / \mathrm{kg}$; range: 330-2300 $\mu \mathrm{g} / \mathrm{kg}$ ), and French fries have $540 \mu \mathrm{g} / \mathrm{kg}$ (range: $300-1100 \mu \mathrm{g} / \mathrm{kg}$ ) .

It is estimated that adults consume a range of 0.3 to 0.6 $\mu \mathrm{g} / \mathrm{kg} /$ day of AA while the average intake of AA for children is more $(0.4-0.6 \mu \mathrm{g} / \mathrm{kg})$. This can be as a result of children's higher caloric intake and their higher feeding of certain acrylamide-rich foods, such as French fries and potato crisps (17).

Peterson and Tran showed that $38 \%$ of the total daily energy intake, in the United States, is coming from foods with high AA levels. These foods supply $47 \%$ of total daily iron, and $42 \%$ of total daily folate. Furthermore, AA was found in cigarette (1-2 $\mu \mathrm{g}$ /cigarette) that made smoking people expose to higher level of AA than nonsmoking people (18).
Dybing et al. have reported that men intake an average equal to $0.36 \mu \mathrm{g} \mathrm{AA} / \mathrm{kg} /$ day while this value for women is lower $(0.33$ $\mu \mathrm{g}$ AA/kg /day). Thirteen years old boys and girls respectively intake 0.52 and $0.49 \mu \mathrm{g} \mathrm{AA} / \mathrm{kg} /$ day. Also consumption of coffee increases these value to $0.49 \mu \mathrm{g}$ AA/kg /day in men and $0.46 \mu \mathrm{g} \mathrm{AA} / \mathrm{kg} / \mathrm{day}$ in women. Men at the age of 16-30 years intake highest level of AA. Interestingly, potato products and coffee were the main sources of AA intake. In Swedish adult, the average dietary intake of AA from food products was estimated approximately $31 \mu \mathrm{g} /$ day (19-20).

In Germany the mean daily intake of AA at age of 7-19 years is $0.3 \mu \mathrm{g}$ AA $/ \mathrm{kg} /$ day and in Netherlands (7-18 years) is $0.71 \mu \mathrm{g}$ AA/kg/day. While the FAO/WHO assumes a range of $0.3-0.8$ $\mu \mathrm{g}$ AA//day for dietary intake in developing countries. Also, In Brazil, as an example from south American countries, the mean AA intakes from foods was estimated to be $0.12 \mu \mathrm{g} / \mathrm{kg} /$ day at range of 11-17 years. Then AA intake by Brazilian adolescents is lower than reported in European countries. These differences can be partially related to the use of different food patterns (21).

\section{Toxicology of acrylamide}

Neurotoxicity of acrylamide

Many studies implicated that AA can be known as a potent neurotoxic agent. In laboratory animals No-observableadverse-effect level (NOAEL) for AA neurotoxicity is $0.2-0.5$ $\mu \mathrm{g} / \mathrm{kg} /$ day and the lowest-observable-adverse effect level (LOAEL) is $2 \mu \mathrm{g} / \mathrm{kg} /$ day.

Whereas the mean dietary exposure estimated by World Health Organization (WHO) is $0.001 \mathrm{mg} / \mathrm{kg} /$ day. Neurotoxicity of AA is the only toxic effects that have been shown both in human occupational exposure and animals. Studies in several species of laboratory animals such as cats, rats, mice, guinea pigs, rabbits, and monkeys revealed that repeated daily exposure of AA results in a triad manifestation effects: ataxia, hind-limb foot splay, and skeletal muscle weakness (22). Liu et al. showed that AA induced apoptosis in rat primary astrocytes lead to mitochondrial dysfunction and apoptosis in BV-2 microglial cells (23).

The neurotoxic effects of AA in workplace environment were determined in many studies (24-25). For example during the building a railroad tunnel near southwest Sweden workers began to develop signs of impaired nerve function, it was as a result of a special gel called Rhoca-Gel, contained AA, that was used to waterproof leaks in the tunnel wall (26). In another study Chen et al. showed that AA disrupted nervous system by inhibiting of human neuroblastoma and gelioblastoma cellular differentiation (27). 


\section{Carcinogenicity and genotoxicity of acrylamide}

AA is classified as a "probable human carcinogen" by International Agency for Research on Cancer (IARC, 1994) (28). There is inadequate evidence of AA carcinogenic effects in humans from epidemiologic studies or occupational exposure. AA has a structure like to carcinogen compounds such as vinyl carbamate and acrylonitrile. However, prolong animals exposed to high concentrations in the drinking water leads to multiple tumors development at multiple sites in both male and female genders (22). Carcinogenicity of AA was explained in very researches. Results showed that AA can increase the risk of some cancers. For example exposure to AA was really associated with kidney, and breast cancers in postmenopausal women (29). However some studies gainsays these results $(28,30)$. Hogervorst et al. found a positive relation between dietary AA and renal cell cancer whereas there are no positive relations with bladder and prostate cancer risk (31).

The genotoxicity of AA and its major metabolite, glycidamide, have been studied in several reviews. Capacity to produce genetic damage is one of the important parameters in assessment of carcinogenicity (22). AA can be able to damage to DNA, for example, studies showed that AA at the dose of 10,20 and $30 \mathrm{mg} / \mathrm{kg}$ significantly induced DNA damage compared with the control group (32). In another study, AA was shown genotoxic effect in cell culture by in vitro tests and in vivo animal models (22).

\section{Reproductive toxicity of acrylamide}

Reproductive toxicity was also evaluated in laboratory animals that received high levels of AA. There is no evidence about reproductive toxicity of AA in human. The No Observed Adverse Effect Level (NOAEL) for reproductive toxicity was assessed to be $2-5 \mu \mathrm{g} / \mathrm{kg} /$ day in rats. This dose is at least four time higher than doses need acrylamide neurotoxicity and 2000 time more than estimated dietary exposures amount (? $35)$.

Furthermore, administration of $0.5-10 \mathrm{mg} / \mathrm{kg}$ of AA retarc growth of rats and decrease epididymal sperm reser compared with control group. In addition, histopatholo, lesions were also present in the testis of treated rats (36).

In one study, after ip injection of AA doses $(20 \mathrm{mg} / \mathrm{kg})$ to $\mathrm{m}$ rats, testosterone and prolactin concentrations were decreas as a dose-dependence manner (37).

In another study, Wei et al. revealed that AA can be toxic female reproductive system in mice. They exhibited that $\mathrm{c}$ doses of AA significantly reduced body weights, organ weights and the number of corpora lutea. AA reduced serum progesterone concentrations as dose depended (38).

\section{Immunotoxicity of acrylamide}

The immunotoxicity of AA were less reported than its neurotoxicity and reproductive toxicity. Nevertheless in a survey done by Jin et al., immunotoxicity of AA found in Female BALB/c Mice. They observed that AA decreased final body weight, spleen and thymus weights, lymphocyte counts. Also, pathological changes were observed in lymph glands, thymus and spleen. They found AA can significantly decrease $\%$ T cells and natural killer (NK) cells, too (5).

\section{Mechanism of acrylamide toxicity}

When there is an imbalance in the biological oxidant to antioxidant ratio, oxidative stress can occur. It could also be an initiator step to many diseases (39-41). Free radicals are constantly produced in vivo. For neutralizing of free radical's adverse effects, the body has protective barriers like antioxidant enzymes (superoxide dismutase (SOD), catalase, glutathione $S$-transferase, glutathione peroxidase) and proteins like GSH (42-43).

In recent years, some studies have demonstrated that AA induced oxidative stress. AA affect the cellular redox chain and it can generate reactive oxygen species (ROS). AA is oxidized to glycidamide and then conjugate with GSH. AA and its metabolite, glycidamide, capable to interact with nucleophiles group in cells (such as $-\mathrm{SH},-\mathrm{NH} 2$ or $-\mathrm{OH}$ ). AA reacts with GSH by helping of glutathione s teransferase. With increase of AA concentration, GST and SOD activity is increased and the GSH count is depleted $(42,44)$. Also, it has been shown that AA can create apoptosis as a result of oxidative stress (23).

Chronic exposure of dietary AA might induce oxidative stress in humans. also increasing of ROS formation and GSH oxidation were observed in isolated human monocyte after exposure to AA (45) (Figure 1).

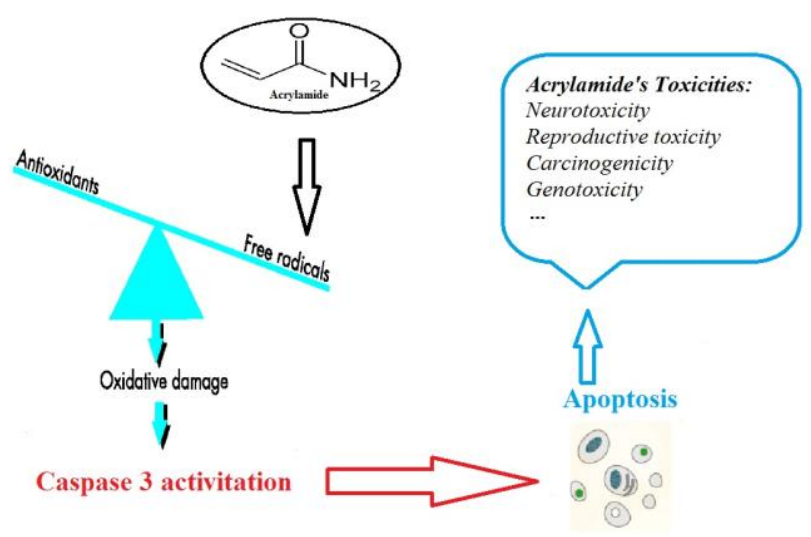

Figure1 Mechanism of acrylamide's toxicity 
Oxidative stress is an introduction for initiation of the most important cell death type such as apoptosis. Sometimes this term is used interchangeably with programmed cell death. Apoptosis is characterized by membrane blebbing, cell shrinkage, chromatin condensation, and fragmentation of DNA. The absence of an inflammatory response in apoptosis distinguishes it from necrosis (46). During this energydependent process, a group of cysteine proteases called Caspases and a complex cascade of procedures cooperates with each other (47). It has a crucial role during development and aging and as a homeostatic mechanism to keep cell populations in tissues. It furthermore, performs as a defense mechanism in immune reactions or when cells are disturbed by disease or harmful agents. After rapidly absorption from intestine, AA is usually nonenzymatically and enzymatically conjugated with glutathione (GSH) ensuing a depletion of cellular GSH stores (48).

The reduction in GSH levels may enhance the levels of reactive oxygen species (ROS), which are widely known as key mediators of cell function (49).

It is shown that ROS generation lead to activate the mitogenactivated protein kinase (MAPK)-JNKs which play an important role in the regulation of cellular processes such as apoptosis (49). Interestingly, several studies showed that cellular glutathione redox imbalance is an important player in apoptotic signaling and cell death in intestinal cells. Therefore, decreased GSH levels result in cellular oxidative stress, and apoptosis may be suggested as a potential mechanism for AA toxicity. Polyphenols in high concentrations can protect the intestinal epithelium from the potential oxidative stress induced by AA (50-51).

Based on previous evidence, the mechanism of degenerating neuronal cell death in neurological disorders like Alzheimer's disease (AD), Parkinson's disease (PD), Huntington's disease, and the inherited ataxias may involve apoptosis. Subchronic exposure to ACR altered the expression of death-related proteins in the CNS and PNS tissue indicating the early molecular regulatory mechanism of apoptosis in the ACR neuropathy (52). Chen et al. demonstrated that long exposure to ACR at a concentration of $2 \mathrm{mM}$ or higher can cause apoptosis and astrogliotic responses in a time- and dose dependent manner in astrocytic cells (U-1240 MG) (53). In another study, the researchers showed that AA increase p53 protein phosphorylation at Ser15 in human neuroblastoma cells (SH-SY5Y) that leads to p53 activation (54). It is well clear that the $\mathrm{p} 53$, as a tumor suppressor gene, plays a main role in neurons' apoptosis (55). Moreover, Sumizawa and Igisu have shown that AA mitigated cell viability in a dose- dependent manner in human neuroblastoma cells (SH-SY5Y). Furthermore, AA increased caspase-3 activity and cell population in sub-G1 phase at a dose of $3 \mathrm{mM}$, while both were less at higher doses $(4$ and $5 \mathrm{mM})(56)$.

The exposure of BV2 cells (mouse microglia cell line) to ACR showed the reduction in cell viability and induced apoptosis in a concentration-dependent manner. Impairment in mitochondrial respiratory chain, an aerobic glycolysis, and lowering expression of the complex I, III, and IV subunits result in ACR toxicity was also observed. A decrease of the mitochondrial membrane potential and the ratio of $\mathrm{Bcl}-2 / \mathrm{Bax}$, lead to activation of the mitochondrion-driven apoptotic signaling. Increase of NFkB expression and downstream inducible nitric oxide synthase (iNOS) and nitric oxide generation, support indirectly a pro-inflammatory effect of ACR. Nrf2 expression was also increased but not its translocation to the nucleus (23).

As mentioned before reproductive toxicity of ACR is related to apoptosis and increasing the caspase- 3 expression in cumulus cells. Cumulus cells surround oocyte and provide crucial nutrients and signals. Cumulus cells are essential for oocyte maturation, including the process of meiotic arrest and resumption (57).

\section{Clinical toxicity}

Although there is clear evidence for reproductive toxic, genotoxic and carcinogenic effects of $\mathrm{AA}$ when given to laboratory animals, these effects in humans exposed to AA has not been established.

However, the neurotoxic properties of AA are the only toxic effect that have been shown in humans (22). Acute and subacute exposure with a high dose of AA can cause severe symptoms of the central nervous system such as drowsiness, disorientation, confusion, hallucinations, memory loss. Also, Long term exposure to AA may produce peripheral polyneuropathy that characterized with symptom such as numbness of lower limbs, tingling of the fingers, tenderness to the touch, decreased pinprick sensation, vibratory loss and weak or absent tendon reflexes (58).

Main health effects of AA in human are skin and respiratory tract irritant. Gua et al. observed that AA and glycidamide (its metabolite) can induce allergy-related outcomes like asthma, hay fever, sneeze, wheeze and eczema in US population (59).

Although, some case studies reported the hepatic, cardiac and renal failures following investigation of water contaminated with $\mathrm{AA}$, there is few epidemiologic evidence that $\mathrm{AA}$ increases risk of these organ failures. A summarized acrylamide toxicities are presented at table 1 . 
Table1 A summary on acrylamide toxicity

\begin{tabular}{|c|c|c|c|}
\hline Population & Objective & Results & References \\
\hline BV-2 microglial cells & $\begin{array}{l}\text { Acrylamide induces } \\
\text { mitochondrial } \\
\text { dysfunction and apoptosis in } \\
\text { BV-2 microglial cells. }\end{array}$ & $\begin{array}{l}\text { Acrylamide induced } \\
\text { apoptosis and mitochondrial } \\
\text { dysfunction in rat primary astrocytes }\end{array}$ & )$(23$ \\
\hline Human & $\begin{array}{l}\text { Health effects of occupational } \\
\text { exposure to acrylamide using } \\
\text { hemoglobin adducts as } \\
\text { biomarkers of internal dose. }\end{array}$ & $\begin{array}{l}\text { acrylamide resulted in reversible } \\
\text { PNS symptoms and hemoglobin } \\
\text { adducts }\end{array}$ & )$(26$ \\
\hline $\begin{array}{l}\text { human neuroblastoma } \\
\text { (SH-SY5Y) }\end{array}$ & $\begin{array}{l}\text { Acrylamide inhibits cellular } \\
\text { differentiation of human } \\
\text { neuroblastoma and glioblastoma } \\
\text { cells. }\end{array}$ & $\begin{array}{l}\text { AA disrupted nervous system by } \\
\text { inhibiting of human neuroblastoma } \\
\text { and gelioblastoma cellular } \\
\text { differentiation }\end{array}$ & )$(27$ \\
\hline Women & $\begin{array}{l}\text { A prospective study of dietary } \\
\text { acrylamide intake and the risk of } \\
\text { endometrial, ovarian, and breast } \\
\text { cancer. }\end{array}$ & $\begin{array}{l}\text { Acrylamide increased risks of } \\
\text { postmenopausal endometrial and } \\
\text { ovarian cancer }\end{array}$ & )$(30$ \\
\hline Male mice & $\begin{array}{l}\text { Protective effect of l-carnitine } \\
\text { against acrylamide-induced } \\
\text { DNA damage in somatic and } \\
\text { germ cells of mice }\end{array}$ & $\begin{array}{l}\text { Acrylamide induced chromosomal } \\
\text { aberrations and micronuclei in bone } \\
\text { marrow cells and morphological } \\
\text { sperm abnormalities }\end{array}$ & )$(32$ \\
\hline Male rats & $\begin{array}{l}\text { Relationship between acrylamide } \\
\text { reproductive and neurotoxicity in } \\
\text { male rats. }\end{array}$ & $\begin{array}{l}\text { epididymal sperm, mating, } \\
\text { and neurotoxic symptoms were } \\
\text { observed after acrylamide } \\
\text { administration }\end{array}$ & )$(34$ \\
\hline Male rats & $\begin{array}{l}\text { Reproductive toxicity of } \\
\text { acrylamide-treated male rats. }\end{array}$ & $\begin{array}{l}\text { Acrylamide decreased growth of } \\
\text { rats and epididymal sperm reserves }\end{array}$ & )$(36$ \\
\hline Female mice & $\begin{array}{l}\text { Reproductive toxicity in } \\
\text { acrylamide-treated female mice. }\end{array}$ & $\begin{array}{l}\text { Acryamide decreased } \\
\text { viability of mouse granulosa cells, } \\
\text { the number of corpora lutea and } \\
\text { progesterone production }\end{array}$ & )$(38$ \\
\hline $\mathrm{BALB} / \mathrm{c}$ mice & $\begin{array}{l}\text { Immunotoxicity of Acrylamide } \\
\text { in Female BALB/c Mice. }\end{array}$ & $\begin{array}{l}\text { Acrylamide inhibited cellular and } \\
\text { humoral immunity of mice }\end{array}$ & )$(5$ \\
\hline Human & $\begin{array}{l}\text { Relationships between } \\
\text { acrylamide and } \\
\text { glycidamide hemoglobin adduct } \\
\text { levels and allergy-related } \\
\text { outcomes in general US } \\
\text { population }\end{array}$ & $\begin{array}{l}\text { Acrylamide promoted asthma, hay } \\
\text { fever, sneeze, wheeze and eczema ir } \\
\text { US population }\end{array}$ & )$(59$ \\
\hline
\end{tabular}

\section{Conclusion}

Adverse effects of AA on several systems such as nervous system, reproductive system and immune systems in animal models were reported. Unfortunately neurotoxicity of AA was observed in human, too. Furthermore AA is highly used in industries and also because of high content of AA in dietary foods, exposure to AA is unavoidable. So it is necessary to know its toxicity effects and mechanisms. In this review, we suggested that oxidative stress can be a mechanism of AA toxicity. Interestingly, using of antioxidant compounds like vitamin $\mathrm{E}$ and carnitine can dramatically decrease its toxicity (32). However, more studies need to prove this subject. Also it seems useful to modify dietary food processing pressures, especially foods with high carbohydrate such as potato chips and French fries, to reduce the AA formation in foods. 


\section{Conflict of interest}

The authors have no conflict of interest to declare.

\section{References}

1. Dearfield KL, Abernathy CO, Ottley MS, Brantner JH, Hayes PF. Acrylamide: its metabolism, developmental and reproductive effects, genotoxicity, and carcinogenicity. Mutat Res 1988;195:45-77.

2. Tareke E, Rydberg P, Karlsson P, Eriksson S, Törnqvist M. Analysis of acrylamide, a carcinogen formed in heated foodstuffs. J Agric Food Chem 2002;50:4998 5006.

3. Claus A, Carle R, Schieber A. Acrylamide in cereal products: A review. J Cereal Sci 2008;47:118-33.

4. Keramat J, LeBail A, Prost C, Jafari M. Acrylamide in baking products: A review article. Food Bioprocess Technol 2011:4:530-43.

5. Fang J, Liang CL, Jia XD, Li N. Immunotoxicity of Acrylamide in Female BALB/c Mice. Biomed Environ Sci 2014;27:401-9.

6. Hawley GG, Lewis RJ. Hawley's condensed chemical dictionary. Van Nostrand Reinhold;(1997).

7. Besaratinia A, Pfeifer GP. A review of mechanisms of acrylamide carcinogenicity. Carcinogenesis 2007;28:51928.

8. Sumner SC, Fennell TR, Moore TA, Chanas B, Gonzalez F, Ghanayem BI. Role of cytochrome P450 2E1 in the metabolism of acrylamide and acrylonitrile in mice Chem Res Toxicol 1999;12:1110-6.

9. Riboldi BP, Vinhas ÁM, Moreira JD. Risks of dietary acrylamide exposure: A systematic review. Food Chem 2014:157:310-22.

10. Hashimoto K, Sakamoto J, Tanii H. Neurotoxicity of acrylamide and related compounds and their effects on male gonads in mice. Arch Toxicol 1981;47:179-89.

11. Edwards PM. The distribution and metabolism of acrylamide and its neurotoxic analogues in rats. Biochem Pharmacol 1975;24:1277-82

12. Dixit R, Mukhtar H, Seth PK, Murti CR. Conjugation of acrylamide with glutathione catalysed by glutathione-Stransferases of rat liver and brain. Biochem Pharmacol 1981;30:1739-44.

13. Ramsey J, Young J, Gorzinski S. Acrylamide: toxicodynamics in rats. Health and Environmenta Sciences, Toxicology Research Laboratory, Dow Chemical USA, Midland, MI 1984

14. Miller M, Carter D, Sipes I. Pharmacokinetics of acrylamide in Fisher-334 rats. Toxicol Appl Pharmacol 1982;63:36-44.

15. Zhang Y, Zhang G, Zhang Y. Occurrence and analytical methods of acrylamide in heat-treated foods: Review and recent developments. J Chromatogr A 2005;1075:1-21.

16. Eriksson S. Acrylamide in food products: Identification, formation and analytical methodology. 2005

17. Dybing E, Farmer PB, Andersen M, Fennell TR, Lalljie SP, Müller DJ, et al. Human exposure and internal dose assessments of acrylamide in food. Food Chem Toxicol 2005;43:365-410.

18. Petersen BJ, Tran N. Exposure to acrylamide. In Chemistry and safety of acrylamide in food Springer;2005. $\mathrm{p}^{\wedge} \mathrm{pp}$ 63-76

19. Svensson K, Abramsson L, Becker W, Glynn A, Hellenäs $\mathrm{K}-\mathrm{E}$, Lind $\mathrm{Y}$, et al. Dietary intake of acrylamide in Sweden. Food Chem Toxicol 2003;41:1581-6.

20. Dybing E, Sanner T. Risk assessment of acrylamide in foods. Toxicol Sci 2003;75:7-15.

21. Arisseto AP, de Figueiredo Toledo MC, Govaert Y, van Loco J, Fraselle S, Degroodt J-M, et al. Contribution of selected foods to acrylamide intake by a population of Brazilian adolescents.LWT - Food Sci technol 2009; 42:207-11.

22. Exon J. A review of the toxicology of acrylamide. J
Toxicol Environ Health B 2006;9:397-412

23. Liu Z, Song G, Zou C, Liu G, Wu W, Yuan T, et al Acrylamide induces mitochondrial dysfunction and apoptosis in BV-2 microglial cells. Free Radic Biol Med 2015;84:42-53.

24. LoPachin RM. The changing view of acrylamide neurotoxicity. Neurotoxicol 2004;25:617-30.

25. Specer PS, Schaumburg HH. A review of acrylamide neurotoxicity. In Part II Experimental animal neurotoxicity and pathologic mechanisms. Can J Neurol Sci 1974;1:152-69.

26. Hagmar L, Törnqvist M, Nordander C, Rosén I, Bruze M, Kautiainen A, et al. Health effects of occupational exposure to acrylamide using hemoglobin adducts as biomarkers of internal dose. Scand J Work Environ Health 2001:219-26

27. Chen J-H, Chou C-C. Acrylamide inhibits cellular differentiation of human neuroblastoma and glioblastoma cells. Food Chem Toxicol 2015;82:27-35.

28. Pelucchi C, Galeone C, Levi F, Negri E, Franceschi S, Talamini R, et al. Dietary acrylamide and human cancer. Int J Cancer 2006;118:467-71.

29. Krishnakumar T, Visvanathan R. Acrylamide in Food Products: A Review. J Food Process Technol 2014;5:2.

30. Hogervorst JG, Schouten LJ, Konings EJ, Goldbohm RA, van den Brandt PA. A prospective study of dietary acrylamide intake and the risk of endometrial, ovarian, and breast cancer. Cancer Epidemiol Biomarkers Prev 2007;16:2304-13.

31. Hogervorst JG, Schouten LJ, Konings EJ, Goldbohm RA, van den Brandt PA. Dietary acrylamide intake and the risk of renal cell, bladder, and prostate cancer. Am J Clin Nutr 2008;87:1428-38.

32. Alzahrani HAS. Protective effect of 1-carnitine against acrylamide-induced DNA damage in somatic and germ cells of mice. Saudi J Biol Sci 2011;18:29-36.

33. Tyl RW, Friedman MA. Effects of acrylamide on rodent reproductive performance. Reprod Toxicol 2003;17:1-13.

34. Tyl RW, Marr MC, Myers CB, Ross WP, Friedman MA Relationship between acrylamide reproductive and neurotoxicity in male rats. Reprod Toxicol 2000;14:14757.

35. Programme WHOFS. Health Implications of Acrylamide in Food: Report of a Joint FAO/WHO Consultation, WHO Headquarters, Geneva, Switzerland, 25-27 June 2002. Diamond Pocket Books (P) Ltd.;(2002).

36. Wang H, Huang P, Lie T, Li J, Hutz RJ, Li K, et al. Reproductive toxicity of acrylamide-treated male rats. Reprod Toxicol 2010;29:225-30.

37. Ali SF, Hong J-S, Wilson WE, Uphouse LL, Bondy SC Effect of acrylamide on neurotransmitter metabolism and neuropeptide levels in several brain regions and upon circulating hormones. Arch Toxicol 1983;52:35-43.

38. Wei Q, Li J, Li X, Zhang L, Shi F. Reproductive toxicity in acrylamide-treated female mice. Reprod Toxicol 2014;46:121-8.

39. Jin $\mathrm{Y}$, Pan $\mathrm{X}, \mathrm{Fu} \mathrm{Z}$. Exposure to bifenthrin causes immunotoxicity and oxidative stress in male mice. Environ Toxicol 2014;29:991-9.

40. Mojtahedzadeh M, Ahmadi A, Mahmoodpoor A Beigmohammadi MT, Abdollahi M, Khazaeipour Z, et al. Hypertonic saline solution reduces the oxidative stress responses in traumatic brain injury patients. J Res Med Sci 2014;19:867.

41. Shaki F, Pourahmad J. Mitochondrial toxicity of depleted uranium: Protection by beta-glucan. IJPR 2013;12:131.

42. Yousef M, El-Demerdash F. Acrylamide-induced oxidative stress and biochemical perturbations in rats. Toxicol 2006;219:133-41

43. Shaki F, Hosseini MJ, Ghazi-Khansari M, Pourahmad J. Toxicity of depleted uranium on isolated rat kidney mitochondria. Biochim Biophys Acta 2012;1820:194050.

44. Chen W, Shen Y, Su H, Zheng X. Hispidin derived from 
Phellinus linteus affords protection against acrylamideinduced oxidative stress in Caco-2 cells. Chem Biol Interact 2014;219:83-9.

45. Naruszewicz M, Zapolska-Downar D, Kośmider A, Nowicka G, Kozłowska-Wojciechowska M, Vikström AS, et al. Chronic intake of potato chips in humans increases the production of reactive oxygen radicals by leukocytes and increases plasma C-reactive protein: a pilot study. Am J Clin Nutr 2009;89:773-7.

46. Renehan AG, Booth C, Potten CS. What is apoptosis, and why is it important? Br Med J 2001;322:1536.

47. Elmore S. Apoptosis: a review of programmed cell death. Toxicol Pathol 2007;35:495-516.

48. Nakagawa-Yagi Y, Choi D-K, Ogane N, Shimada S-i, Seya M, Momoi T, et al. Discovery of a novel compound: insight into mechanisms for acrylamide-induced axonopathy and colchicine-induced apoptotic neuronal cell death. Brain Res 2001;909:8-19.

49. Valko M, Leibfritz D, Moncol J, Cronin MT, Mazur M, Telser J. Free radicals and antioxidants in normal physiological functions and human disease. Int $\mathrm{J}$ Biochem Cell Biol 2007;39:44-84.

50. Circu ML, Rodriguez C, Maloney R, Moyer MP, Aw TY. Contribution of mitochondrial GSH transport to matrix GSH status and colonic epithelial cell apoptosis. Free Radic Biol Med 2008;44:768-78.

51. Rodríguez-Ramiro I, Ramos S, Bravo L, Goya L, Martín MÁ. Procyanidin B2 and a cocoa polyphenolic extract inhibit acrylamide-induced apoptosis in human Caco-2 cells by preventing oxidative stress and activation of JNK pathway. J Nutr Biochem 2011;22:1186-94.
52. Li S-x, Cui N, Zhang C-1, Zhao X-1, Yu S-f, Xie K-q Effect of subchronic exposure to acrylamide induced on the expression of bcl-2, bax and caspase- 3 in the rat nervous system. Toxicol 2006;217:46-53.

53. Chen Z, Chen Z, Chen $H$, Chen $H$, Zhou $T$, Lu H. Schwann cell apoptosis in Wallerian-degenerated sciatic nerve of the rat. Chin J Traumatol 2004:7:220-8.

54. Okuno $T$, Matsuoka $M$, Sumizawa $T$, Igisu $H$. Involvement of the extracellular signal-regulated protein kinase pathway in phosphorylation of $\mathrm{p} 53$ protein and exerting cytotoxicity in human neuroblastoma cells $(\mathrm{SH}-$ SY5Y) exposed to acrylamide. Arch Toxicol 2006;80:146-53

55. Morrison RS, Kinoshita Y, Johnson MD, Guo W, Garden GA. p53-dependent cell death signaling in neurons. Neurochem Res 2003;28:15-27.

56. Sumizawa T, Igisu H. Apoptosis induced by acrylamide in SH-SY5Y cells. Arch Toxicol 2007;81:279-82.

57. Liu S, Jiang L, Zhong T, Kong S, Zheng R, Kong F, et al. Effect of Acrylamide on Oocyte Nuclear Maturation and Cumulus Cells Apoptosis in Mouse In Vitro. PLoS One 2015;10:e0135818.

58. Igisu H, Goto I, Kawamura Y, Kato M, Izumi K. Acrylamide encephaloneuropathy due to well water pollution. J Neurol Neurosurg Psychiatry 1975;38:581-4.

59. Guo J, Yu D, Lv N, Bai R, Xu C, Chen G, et al. Relationships between acrylamide and glycidamide hemoglobin adduct levels and allergy-related outcomes in general US population, NHANES 2005-2006. Environmental Pollution. 